\title{
БАЛКАНЫ, ГЕРМАНИЯ И АВСТРО-ВЕНГРИЯ НАКАНУНЕ И В ГОДЫ МИРОВОЙ ВОЙНЫ В ЭСТОНСКОЙ НАЦИОНАЛЬНОЙ ИСТОРИОГРАФИИ МЕЖВОЕННОГО ПЕРИОДА
}

\author{
АРТЁМ А. УлунЯН
}

\begin{abstract}
ABSTRACт. Улунян Артём. А., Балканы, Германия и Австро-Венгрия накануне и в годы мировой войны в эстонской национальной историографии межвоенного периода (Balkans, Germany and AustriaHungary on the eve and during the first word war in Estonian national historiography of the interwar period).
\end{abstract}

Balcanica Posnaniensia. Acta et studia, XIX, Poznań 2012, Wydawnictwo Instytutu Historii UAM, pp. 181-196, ISBN 978-83-63-047-17-7, ISSN 0239-4278. Russian text with a summary in English.

Artyom A. Ulunyan, Doctor of Sciences (History), Head of the Center for Balkan, South Caucasian and Central Asian historical Studies, Institute of General History, Russian Academy of Sciences, Leninski prospect 32-A, Moskva.

Обращение эстонских историков к теме международных отношений в Балканском регионе второй половины XIX в. - первых двух десятилетий $\mathrm{XX}$ в. и проблемам региональной политики основных европейских держав, включая Австро-Венгрию, было во многом обусловлено проявившимся в эстонской историографии интересом к роли и месту империй в формировании картины мира накануне и после Первой мировой войны, одним из результатов которой был их распад и создание новых национальных государств, включая Эстонию. В этой связи отчётливо выявились преференции в «эстонском взгляде» на значимость конкретных стран в международных процессах. Объяснимое с точки зрения эстонских исторических реалий выдвижение на первое место историками-авторами публикаций по международным отношениям на Балканах места Российской и Германской империй не означало игнорирование ими роли Британии, Австро-Венгрии, Османской империи, Италии и Франции. Несмотря на то, что в 20-е - 30-е г. XX в. началось лишь становление эстонской национальной исторической школы исследований всемирной истории нового и новейшего времени, она, тем не менее, имела серьезный потенциал и перспективу развития. Образованное при Тартуском Университет в 1920 г. Академическое историческое общество (Akadeemiline Ajaloo Selts) было призвано способствовать развитию исторических исследований по широкому спектру проблем, включая период новой и новейшей истории зарубежных государств. Его печатным органом стал созданный в 1922 г. «Исторический журнал («Ajalooline 
Ajakiri»). Значимость этого ежеквартального академического издания, публиковавшегося на протяжении 1922 - 1940 гг,, была отмечена в 1928 г. современником событий, известным эстонским историком Юханом Либе в его статье «Обзор нашей исторической литературе, вышедшей в 1927 г.», в которой он писал, что «“Исторический журнал”, вышедший в прошлом, седьмом году существования журнала, как таковой, является одним из немногих эстоноязычных чисто научных изданий, добившихся серьезного успеха как по содержанию, так и в распространении» ${ }^{1}$. Тираж журнала до 1930 г. составлял 1000 экземпляров, но затем сократился². Эта тема обсуждалась в январе 1939 г. на заседании руководства Академического исторического общества, существовавшим в 1920-1941 гг. при Тартуском Университете, и издававшим журнал. До 1940 г., когда было публиковано только 2 номера, в свет вышло 74 номера. В 1941 г., уже после утери Эстонской Республикой независимости, включения её в Советский Союз и превращения в Эстонскую ССР, советскими властями была предпринята попытка «советизации» «Исторического журнала», что ознаменовалось изданием трёх номеров откровенно пропагандистского содержания, после чего он был закрыт. На протяжении почти двадцатилетнего существования журнала в нём помещались работы как эстонских, так и зарубежных историков. Несмотря на то, что подавляющая часть публиковавшихся статей и рецензий прямо или косвенно была посвящена национальной истории Эстонии, а также соседних с ней по Балтийскому региону государств и народов, предпринимались попытки развивать и такие направления исторической науки как методология исторических исследований, философия истории, а также история европейских стран и народов с древности и до новейшего времени. с приходом на должность главного редактора издания профессора Тартуского Университета Пеэтра Тарвела (до эстонизации в 1935 г. его фамилия звучала как Драйберг и Трейберг), являвшегося в 1925-1940 гг. председателем Академического исторического общества, тематика всеобщей истории получила в журнале дополнительное развитие. Это было обусловлено личной заинтересованностью Тарвела в развитии исследований по истории европейских стран в новое и новейшее время, так как он сам занимался эпохой Великой французской революции и британской историей XIX-XX в. ${ }^{3}$ Помимо научно-преподавательской деятельности Тарвел был активным общественно-политическим деятелем и членом Рийгикогу от одной из крупнейших партий - Эстонской социал-демократической рабочей партии (переименованной в 1925 в Эстонскую социалистическую рабочую партию). Её ру-

${ }^{1}$ Libe J. Ülevaade meie ajalookirjandusest läinud (1927.) aastal.// Eesti Kirjandusest. №. 5. 1928. Ввиду недоступности бумажной версии цитируется по электронному ресурсу - http://www. kirjandusarhiiv.net/? $=121$

2 Rosenberg T. Ajalooline Ajakiri 1922-1940// Kleio. Ajaloo Ajakiri. N 8. 1993. Lk. 27.

3 П. Тарвел (1894-1953) являлся в Санкт-Петербургском Университете учеником русского историка Н. Кареева. Подробнее о жизни и деятельности П. Тарвела в: Kivimäe J. Peeter Tarveli elu ja töö// Akadeemia. №9,1989; №1,1990. 
ководство активно участвовало в составлении текста Конституции Эстонской Республики 1920 г.

Во второй половине 30-х гг. в журнале стали публиковаться специализировавшиеся по проблемам новой и новейшей истории европейских государств его ученики - Лейда Лооне (до 1934 г. - Ребане) ${ }^{4}$, а также Леммит (до 1937 г. Леонхард) Марк ${ }^{5}$ - магистрант известного шведского историка Стена Ингвара Карлинга, преподававшего в Тартуском Университете в 1933-1941 гг., Марта Соргсепп $^{7}$, Херман Фишер ${ }^{8}$.

Появление в 1928 г., спустя десять лет после опубликования манифеста о независимости Эстонии, сборника статей «Побуждающая мотивация I: Мысли борца-республиканца», с подзаголовком «Десять лет испытаний», было расценено частью эстонского общества как скандальный факт, так как в этом издании фактически проводилась мысль о том, что борьба за независимость Эстонии не привела к желаемым результатам. В число материалов сборника, помимо переводной статьи Р. Ролана, был включены эссе и заметки эстонских авторов историков, культурологов, фольклористов и журналистов, принадлежавших к национал-демократическому левоцентристскому спектру общественной мысли страны. Среди участников сборника был Аугуст Аннист (до эстонизации его фамилии в 1936 г. Анни) ${ }^{9}$, поместивший несколько своих небольших эссе, включая

4 Л. Лооне (1911-1969) впоследствии занималась национальной эстонской историей XVIIIXIX вв.

${ }^{5}$ Rosenberg T. Ajalooline Ajakiri 1922-1940// Kleio. Ajaloo Ajakiri, N 8. 1993. Lk. 30.

6 Л. Марк (1912-1962) стал известен в эстонской историографии как специалист по средневековью. Будучи лишён в годы советской власти возможности работать по специальности, он, тем не менее, не отказался от научных исследований и оставил после своей смерти рукописи «Старая эстонская историография» и «Освободительная война в древности», хранящиеся ныне в архиве Тартуского Университета.

7 Данные о судьбе М. Соргсепп (1910 - ?), к сожалению, не были выявлены и можно лишь отметить её активное участие в работе Академического исторического общества до 1940 г. Встречается написание её имени и фамилии как Martha Sorgsep. См. информацию о получении ею диплома Тартуского Университета в: Ülikooli lõpetasid//Postimees, 18.09 1934. Lk. 7.

${ }^{8}$ Более подробные сведения о Х. Фишере (1903 - ?) выявить не удалось. Помимо его статей, опубликованных в «Историческом журнале», существует газетная публикация по истории Эстонии начала XX в. «Борьба царских властей против газеты “Postimehe” 1900. -1910.» (H. Fisher. «Postimehe» võitlus tsaarivõimudega 1900. - 1910.// Postimees, 17.6.1937, там же помещён портрет $\mathrm{X}$. Фишера) известно о его магистерской диссертации «Политика Великих держав на Дальнем Востоке в период от заключения Симоносекского мирного договора до начала русско-японской войны (1895-1904)», защищенной в Тартуском Университете в 1934 г. -- Fischer H. Suurriikide poliitika Kauges-Idas Šimonoseki rahust kuni Wene-Jaapani sõja puhkemiseni (1895.-1904.) Magistritöö. Tartu Ülikool.Tartu, 1934.

${ }^{9}$ А. Аннист (1899-1972) - эстонский публицист, литературовед и переводчик. Подробнее о нем см. статью Хелены Сепп «Национал-демократический культурный идеал Аугуста Анни(ста) в ранние годы Эстонской Республики и в эпоху безмолвия». - Sepp H. August Anni(sti) rahvuslikdemokraatlik kultuuriideaal Eesti Vabariigi algusaastail ja vaikival ajastul // Acta Historica Tallinnensia. № 12. 2008. В соответствии с существующей эстонской национальной традицией «Эпохой безмолвия» (vaikiv ajastu) называется период 1934-1940 гг., когда у власти находился авторитарный глава страны К. Пятс. Само словосочетание было введено премьер-министром Каарелом Ээнпалу, 
и подписанный псевдонимом «Филолог» ${ }^{10}$ материал «Дилетантские размышления об обществе, интеллигенции, политике и другом» ${ }^{11}$. Обращение А. Анниста к новейшей истории Австрии после распада Двуединой монархии делалось им в тесной связи с усилением после Первой мировой войны социал-демократии в общественно-политической жизни европейских государств. В политических воззрениях австрийских, скандинавских и британских интеллектуалов и интеллигенции (эти два понятия были для него синонимами - intellektuaale, intelligents ), ${ }^{12}$ к примеру которых он апеллировал, Аннист выделял в первую очередь их социальную и национальную ориентированность и отказ от радикальности в их идеологических программных установках ${ }^{13}$. В определенной степени такая интерпретация взглядов социал-демократов была обусловлена его стремлением представить их как образец для соответствующих политических сил собственно Эстонии на пути сближения с Европой. Основной идеей становился поиск приемлемого для эстонских условий сочетания национальной, социальной, политической идентичности, и упоминание австрийского примера наряду со скандинавским не был случаен, имея в виду превращение Австрии в независимое государство-республику после распада Австро-Венгрии. Поражение Двуединой монархии в Первой мировой войне и последствия ее распада привлекало внимание эстонских интеллектуалов-гуманитариев в контексте общенационального дискурса в рамках поиска культурно-исторической и политической идентичности, что нашло своё отражение в проявившемся интересе к ситуации, скидывавшейся в национальной литературе появившихся после исчезновения АвстроВенгрии новых национальных государств. Известный в межвоенной Эстонии литературовед-славист и переводчик Бернхард Линде ${ }^{14}$ первую из серии сво-

выступившим с заявлением о необходимости ограничить деятельность оппозиционных сил, способных дестабилизировать ситуацию в стране. Во многом это было обусловлено действиями военизированной организации ветеранов освободительной войны 1918-1920 гг, которая предприняла попытку государственного переворота в 1934 г.

10 О принадлежности псевдонима «Филолог» А. Аннисту и о формировании группы интеллектуалов вокруг сборника см. в. магистерской работе Моники Таза «Национальный ученый Оскар Лооритс и его время». - Tasa M. Rahvusteadlane Oskar Loorits ja tema kaasaeg (1920-1940). Magistritöö. Tartu Ülikool Filosoofiateaduskond Kirjanduse ja rahvaluule 3+2 õppekava. Tartu, 2008. Lk. 27.- http://dspace.utlib.ee/dspace/bitstream/handle/10062/26098/MA_Tasa.pdf?sequence=1

${ }^{11}$ Filoloog. Võhiku mõtteid ühiskonnast, intelligentsist, poliitikast ja muust.// Dünamis I: Mõtteid võitlevast vabariigist. Tartu, 1928. Во многом рассуждения на эту тему были продолжением идей, изложенных в статьях А. Анниста, опубликованных в 1923 г. в сборнике «Размышления о зрелости интеллигенции». - Mõtteid valmivast intelligentsist. Tartu, 1923.

12 Примечательным было использование А. Аннистом терминов сельская (maaharitlased) и городская (linnaharitlased) интеллигенция. Ввиду недоступности бумажной версии статьи цитируется по электронной: Filoloog. Võhiku mõtteid ühiskonnast, intelligentsist, poliitikast ja muust// Dünamis I: Mõtteid võitlevast vabariigist. Tartu, 1928. - http://www.kirjandusarhiiv.net/?p=651

13 Filoloog. Op. cit.

14 Б. Линде (1886-1954) являлся одним из популярных публицистов и литературоведовславистов. 
их статей по этой теме ${ }^{15}$ посвятил современной ему венгерской литературе, опубликовав в мартовском (1929 г.) номере ежемесячного литературном журнале «Looming» («Творчество») статью «Взгляд на современную венгерскую литературу» ${ }^{16}$. Через анализ существовавших в 20 -е гг. XX в. литературных направлений Б. Линде попытался определить вектор общественно-политического дискурса в независимой Венгрии, имея в виду, что она, как и Эстония, стала независимым государством после Первой мировой войны. Особое внимание в этой связи придавалось соотношению традиционализма и общеевропейских принципов в национальном общественно-культурном пространстве страны. Так, в частности, он обращал внимание на приходившее в начале XX в. в венгерской литературе на смену так называемого национально-консервативного направления нового, связанного с группой писателей, ориентировавшихся на Западную Европу. Среди них он выделял левых по своим взглядам (о принадлежности к этому спектру общественно-политической жизни Венгрии Линде, вероятно, преднамеренно умолчал) поэта Эндре Ади (Endre Ady) и писателя Михая Бабича (Mihály Babits) с их журналом «Nyugat» («Запад»), созданном в 1908 г и прекратившем существование в 1941 г., вокруг которого объединялась демократически настроенная либеральная венгерская интеллигенция ${ }^{17}$. Одновременно Линде отмечал и оформление противоположного ему направления - вокруг литературного журнала «Napkelet» («Восток»), идеологом которого была известная венгерская писательница Сесилия Тормай (Cécile Tormay), стоявшая на позициях венгерского национализма, относившаяся к правому политическому лагерю, резко выступавшая против венгерской коммунистической революции во главе с Б. Куном и территориальных изменений в отношении Венгрии после Первой мировой войны. Обращаясь к ситуации, складывавшейся в венгерской литературе, Линде давал собственную интерпретацию исторической судьбы собственно Венгрии после распада Двуединой монархии, отмечая, как он называл его, «несправедливый мирный договор после Мировой войны, оторвавший от Венгрии

15 См. статьи Б. Линде, посвященные развитию чешской, югославской и польской новейшей литературы: Linde B. Tšehhi kirjanduslik tänapäev//Looming. № 1. 1930; Linde B. Pilguheit jugoslaavia oleviku kirjanduslikku olukorda//Looming. № 4. 1932; Poola kirjanduslikke portreid// Looming. № 2,8.1937.

16 Linde B. Pilk Ungari kirjanduslikku tänapäeva // Looming. 1929. № 3.

17 В действительности, в сложившейся традиции оценки поколений писателей и поэтов, работавших с журналом, вышеупоминаемые литераторы относятся к первому поколению. Второе поколение было представлено Лёринцем Сабо, Дьёрдем Шакёзи, Аттилой Йожефом и др., общественнополитическая ориентация которых включала широкий спектр от правого до коммунистического направления. Третье поколение - это писатели и переводчики, работавшие в 30-е - начале 40-х гг. XX в., в числе которых были Антал Серб, Габор Халош, Ласло Кальноки и др. Все номера журнала доступны по электронному адресу: http://epa.oszk.hu/00000/00022/nyugat.htm. Подробнее о развитии различных направлений в венгерской литературы и их роли в общественно-политической жизни см.: Fenyo M. Literature and Political Change: Budapest, 1908-1918. Transactions of American Philosophical Society. Pliladelphia, 1987; Grendel L. A modern magyar irodalom története: magyar líra és epika a 20. században. Pozsony, 2010. 
исконно венгерские земли, передав их Румынии, Югославии и Чехословакии, что сейчас подтверждается так называемой трансильванской литературой...», которая, как он считал, «занимает теперь важное место» среди литературы новых государств ${ }^{18}$.

Обращение к теме Первой мировой войны, роли в ней противостоявших блоков государств и конкретных стран проходило в эстонской историографии крайне медленно, что объяснялось объективными причинами: отсутствием специалистов, а также повышенным интересом к национальной эстонской истории после освободительной войны 1918-1920 гг. и создания независимого эстонского государства. Одной из первых книг по этой теме стала изданная в Тарту под эгидой Эстонского литературного общества в 1932 г. публицистическая по своему стилю брошюра Г. Уэллса, переведённая на эстонский язык молодым историком Лейдой Ребане (Лооне) с предисловием А. Анни (Анниста), и носившей в эстонском варианте название «Великая мировая война: после неё и перспективы человечества» ${ }^{19}$. В 1939 г. она была переиздана. Первой попыткой создания научного труда стало написание популярной истории Первой мировой войны до заключения Тартуского мира. Инициатором этого проекта выступил бывший в 1919-1920 гг. министром обороны Август Ханко. Под его редакцией и с участием Кооператива эстонских издателей в 1937 г. начался выпуск серии «Мировая война» («Maailmasõda»). До потери национального суверенитета Эстонской Республики и вхождения в состав СССР вышло четыре книги первого тома «Военные события 1914 г.» («Maailmasõda: 1914 -1918. 1914. aasta sõjasündmusi»). Эта работа являлась единственным изданием такого уровня с обзором событий, хотя и имело компилятный характер.

Ситуация, складывавшаяся в эстонской национальной историографии нового и новейшего периодов всемирной истории во многом объяснялась общественно-политическими и культурно-историческими реалиями Эстонии, что обусловило пристальное внимание авторов исследований к роли и месту «германского фактора» в событиях международной жизни конца XIX - начала $\mathrm{XX}$ в., накануне и в годы Первой Мировой войны. Значительная роль в формулировании подходов к изучению международных отношений и, в частности, внешней политики Германии и Австро-Венгрии принадлежала П. Тарвелу, опубликовавшему в 1922 г. одну из первых статей по данной проблеме в «Историческом журнале». Она называлась «Бисмарк и Вильгельм II в свете новых источников» ${ }^{20}$. Её суть сводилась к выяснению причин неудачи германской внешней политики, что нашло своё выражение в поиске автором ответа на вопрос о том, являлось ли поражение Германии личной виной Вильгельма II или

18 Цит. по электронной версии: Linde B. Pilk Ungari kirjanduslikku tänapäeva // Looming. № 3. 1929. - http://www.kirjandusarhiiv.net/?p=281

19 Wells H. Suur maailmasõda : selle järelaeg ja inimsoo tulevikusihid. Tõlkinud L. Rebane; eessõna: A. Anni ; kaas: R. Kivit. Tartu, 1932.

20 Treiberg P. Bismarck ja Wilhelm II uute allikate valgustusel// Ajalooline Ajakiri. № 2.1922. 
системным провалом германской внешней политики в целом. Основными источниками для П. Тарвела, как он отмечает это сам, были ставшие достоянием общественности и оказавшиеся в распоряжении историков опубликованные после войны материалы, главными из которых, как он считал, являлись секретные документы, «переписка между важными историческими личностями (в частности между Николаем I и Вильгельмом), донесения иностранных послов о происходившем в Берлине», среди которых он особо выделял австрийских и бельгийских дипломатов ${ }^{21}$. В этой связи следует отметить, что эстонский историк, вероятнее всего, пользовался изданной в США в 1920 г. перепиской между российским императором и германским кайзером ${ }^{22}$, так как русскоязычное издание было предпринято лишь в $1923 \Gamma^{23}$ Выводы Тарвела были сформулированы в виде двух основных тезисов. Во-первых, «крушение проводимой Бисмарком внешней политики, базирующейся на сложной коалиционной системе, позже привело к тому, что Германия осталась одна». Во-вторых, «отсутствие достойного наследника [Бисмарка] привело к утере германской дипломатией доминирующих позиций в Европе, и в этом смысле падение германского канцлера ощущалось в международном масштабе как шок» ${ }^{24}$. Не менее жёстко Тарвел характеризовал способы и методы создания новой системы международных отношений, основы которой закладывались Версальским мирным договором 1919 г. Его оценка отражала общественно-политических взглядов эстонского историка в целом. В двух номерах «Исторического журнала» в 1924 г. была опубликована его большая статья «Версальский мир 1919 г. на основе новых явлений», посвященная анализу как конкретно-исторической ситуации, сложившейся в международных отношениях и роли в её формировании отдельных государств, так и социологической значиомсти Версальской миросистемы ${ }^{25}$. Оценка Парижского мирного конгресса 1919 г. Тарвелом делалась как «важнейшего из событий международной политики последнего времени, наряду с предыдущими крупнейшими международными событиями, каковыми являлись Венский и Берлинский конгресс», «величайшего эксперимента мировой империалистической политики по решению проблем на основе права и справедливости, при продолжающих доминировать во внешней политике принуждении, силы и политических интересов их [империалистических государств] господствующего положения», а также примером того, что «никогда не было большего

21 Цит. по электронной версии: Treiberg P. Bismarck ja Wilhelm II uute allikate valgustusel// Ajalooline Ajakiri. № 2. 1922. - http://www.kirjandusarhiiv.net/?p=482

${ }^{22}$ Letters From The Kaiser To The Czar Copied From Government Archives In Petrograd. Unpublished Before 1920 private Letters From The Kaiser To The Czar Found In A Chest After The Czar's Execution and Now In Possession Of The Soviet Government Copied And Brought From Russia By Isaak Don Levine. New York, 1920.

23 Переписка Вильгельма II с Николаем II. 1894 - 1914. М.- Пг., 1923.

24 Цит. по электронной версии: Treiberg P. Bismarck ja Wilhelm II.

25 Treiberg P. Versailles’i rahu a. 1919 unemate avalduste põhjal// Ajalooline Ajakiri. № 3, 4. 1924. 
поучительного банкротства, чем попытка Вильсона в Париже», стремившегося «отбросить костыли старой дипломатической традиции» ${ }^{26}$. Акцент на исключительно на захватнические интересы государств-участниц Первой мировой войны нашёл своё отражение в оценке П. Травелом особенно тех из стран, которые проявляли колебания и занимали выжидательную позицию в ходе войны с целью получения от одного из двух противостоявших военных блоков обещаний о гарантий своей захватнической политики. В этой связи приводились примеры. Италии и Румынии. В отношении первой из них автор статьи писал: «Италия, которая по словам её собственного министра иностранных дел Саландра испытывала чистый эгоизм - sacro egoismo, не собиралась присоединяться к союзным державам вплоть до подписания Лондонского договора 26 апреля 1915 г., который гарантировал ей военные трофеи в виде территорий Трентино, Триеста, Горицы и Градишки, части Тироля и Далмации (без Фиуме), территорий, основное или даже большинство населения которых составляют немцы, славяне, албанцы и греки». Позиция Румынии характеризовалась с учётом того, что она «обеспечила себя подобного рода секретным соглашением в 1916 по поводу Трансильвании, Баната, Буковины, в то время как Франция добилась признания от союзников присоединения в свою пользу Эльзаса и Лотарингии, Саарского угольного бассейна и всего левого берега Рейна, отделив [эти йрайоны] от Германии...» ${ }^{27}$ к концу 30-х гг. и ближе к началу Второй мировой войны общественно-политические взгляды П. Тарвела всё сильнее влияли на его исторические исследования и нашли проявление в достаточно острой антиимпериалистической риторике, использовавшейся в анализе системы международных отношений. Он считал, что именно имперская составляющая внешней политики многих государств мира определяла суть происходившего на международной арене. Симптоматичным было появление в 1939 г. в «Историческом журнале» статьи Тарвела «Империализм как новейший исторический период» ${ }^{28}$. Несмотря на определенное созвучие названия с написанной главой российских большевиков В. Ульяновым (Лениным) в 1916 г. работой «Империализм как высшая стадия капитализма», его объяснение происходящего в системе международных отношений отличалось от большевистского. Ссылаясь на концепцию Гоббса о природе человека и о постоянной борьбе за власть в обществе, он отмечал, что со временем появляются более цивилизованные формы власти, что это происходит под воздействием таких факторов как право и мораль и поэтому более развитые государства используют для расширения своей власти в отношении других стран не только военные методы, но мирные способы культурной ассимиляции. Он писал, что надежды революционно настроенных социалистов на крушение капитализма в результате мировой войны не оправдались

${ }^{26}$ Цит. по электронной версии: Treiberg P. Versailles'i rahu a. 1919 uиemate avalduste põhjal// Ajalooline Ajakiri. № 3. 1924. - http://www.kirjandusarhiiv.net/?p=451

27 Ibid.

${ }^{28}$ Tarvel P. Imperialism kui uusima ajaloo periood// Ajalooline Ajakiri. № 4. 1939. 
и единственный путь в сложившейся ситуации это - давление на власть в интересах расширения участия представителей всех общественных слоев в решении политических и социальных вопросов ${ }^{29}$. Являясь сторонником национального суверенитета и демократической формы общественно-политического устройства государства ${ }^{30}$, Тарвел развивал социологический подход к изучению международных отношений, чем оказывал сильное влияние на молодое поколение формировавшихся историков. В определенной степени это проявилось в опубликованном в 1940 г. сборнике «Власть и дух», изданном под эгидой Эстонского студенческого общества . В нём пропагандировалась идея национальной демократии. Помимо П. Тарвела и А. Анниста в работе приняли участие и молодые ученые, в частности Лейда Лооне,$^{31}$ занимавшаяся с начала $30-$ х гг. исследованиями международных отношений. Её статья в вышедшем в 1932 г. под редакцией А. Анниста сборнике, посвященном 300-летнему юбилею Тартуского Университета, называвшаяся «Англо-германские отношения накануне Первой мировой войны (1908-1912 гг.)», ${ }^{32}$ была одной из первых. Хронологические рамки исследования, представлявшего анализ внешнеполитических действий двух империй, включал период с момента аннексии Австро-Венгрией Боснии и Герцеговины и до Балканских войн. Роль Германии в системе международных отношениях рассматривалась Лооне как наиболее значимая, в связи с чем автор статьи обращала первостепенное внимание на англо-германское соперничество как инициирующий фактор будущего возможного мирового конфликта: «Сначала Германия являлась державой, превосходящей над другими европейскими странами, чего было нельзя избежать. В достижении своих мировых гегемонистских целей она была вынуждена столкнуться с конкуренцией со стороны Британии, и было неизбежно их острое столкновение. Британия являлась ведущей индустриально-торговой колониальной державой» ${ }^{33}$. Как полагала автор статьи, противоречия Великобритании и Германии в этой схеме начинали приобретать решающее значение в соответствии с анализом, сделанным автором статьи: «По мнению Германии мощная армия была достаточна для проведения

${ }^{29}$ Цит. по электронной версии: Tarvel P. Imperialism kui uusima ajaloo periood// Ajalooline Ajakiri. № 4.1939. - http://www.kirjandusarhiiv.net/?p=514

30 Подробнее об этом, а также его работы по данной теме были опубликованы в сборнике «Будущее демократии» в Тарту в 2002 г.: Tarvel P. Demokraatia tulevik. Koostajad: Toomas Karjahärm ja Hando Runnel. Tartu, 2002.

31 Võim ja vaim: album Eesti Üliõpilaste Selts «Veljesto» 20-ks aastapäevaks. Tartu 1940. Символичным в данном контексте стало название исследования эстонских историков Т. Карьяхярма и В. Сирка, посвященного эстонской интеллигенции 1917-1940 гг. - «Дух и власть. Эстонская интеллигенция 1917-1940». - Karjahärm, T. , Sirk , V. Vaim ja võim. Eesti haritlaskond 1917-1940. Tallinn, 2001.

32 Rebane L. Inglise-Saksa suhted enne maailmasõda a. 1908-1912.// Kultuuri ja teaduse teilt : mõtteid ja uurimusi. Tartu Ülikooli 300-nda mälestusaasta puhuks. Tartu, 1932.

33 Цит. по электронной версии: Rebane L. Inglise-Saksa suhted enne maailmasõda a. 1908-1912.// A. Anni jt (toim). Kultuuri ja teaduse teilt : mõtteid ja uurimusi Tartu Ülikooli 300-nda mälestusaasta puhuks. Tartu, 1932. - http://www.kirjandusarhiiv.net/?p=717 
империалистической политики. Провалу англо-германских переговоров способствовала на этот раз политическая некомпетентность немецких дипломатов. Империалистические руководители Германии обычно не просчитывали трезво реальную ситуацию, а делали упор только на значение Германии» ${ }^{34}$. Этот «германоцентризм» в определении главных акторов международных отношений, проявившийся у Л. Лооне, достаточно чётко обозначился в заключении упоминаемой статьи, когда она писала: «Англо-германский баланс в Европе существовал всё ещё по другим вопросам, ожидая решения в ходе войны» ${ }^{35}$.

Боснийский кризис 1908 г. рассматривался первым поколением эстонских историков, начинавших специализироваться по истории международных отношений, именно в контексте внешней политики Германии и её внешнеполитических планов. Достаточно показательной стала публикация в 1935 г. в первом и втором номерах «Исторического журнала» статьи Л. Марка «Германская политика по Боснийскому вопросу в 1908-1909 гг.» ${ }^{36}$. Её автор готовился к защите в 1936 г. в Тартуском Университете магистерской диссертации по теме «Русско-английские отношения в первом десятилетии XX века» ${ }^{37}$. Отмечая тот факт, что «основными соперниками в Балканском вопросе были Россия и Австро-Венгрия» ${ }^{38}$, он, тем не менее, обращал внимание в целом на характер внешней политики Берлина и задачи, стоявшие перед ним на международной арене. В этой связи Марк определял основные проблемы, объективно существовавшие в повестке дня германской дипломатии. По его мнению, так как «начало конфликта можно было ожидать по двум основным вопросам - Эльзасу-Лотарингии и будущему Турции», германская сторона была должна готовиться нейтрализовать потенциальных противников и приобрести союзников. В более конкретном виде это означало, что Германия «должна была изолировать Францию, а, с другой стороны, предотвратить кризис в Турции» ${ }^{39}$. Германии, в целях ослабления французских позиций, предстояло «получить потенциальных союзников Франции в лице России, Австрии, Италии и Англии». В то же время, «в Балканском вопросе усиление России за счёт Турции должно было усилить зависть у Австрии и, наоборот [в случае усиления Австрии у России $] \gg^{40}$. Исследуя алгоритм и принципы реализации внешнеполитических планов Германии, Л. Марк обращался к принципам внешней политики О. Бисмарка, считая его более сильным политиком, чем те, кто пришёл ему на

34 Ibid.

35 Ibid.

36 Mark L. Saksa poliitika Bosnia küsimuses 1908.-1909. aastal.//Ajalooline Ajakiri. № 1. 1935. Mark L. Saksa poliitika Bosnia küsimuses 1908.-1909. aastal.//Ajalooline Ajakiri. № 1; 2. 1935.

37 Mark L. Vene-inglise suhted XX sajandi 1. kümnendil. Magistritöö üldise ajaloo alalt..Tartu Ülikool. Tartu, 1936. K. 1, 2.

38 Цит. по электронной версии: Mark L. Saksa poliitika Bosnia küsimuses 1908.-1909. aastal.// Ajalooline Ajakiri. № 1. 1935.- http://www.kirjandusarhiiv.net/?p=576

39 Ibid.

40 Ibid. 
смену. Поэтому особое внимание автор уделял действиям Германии на балканском направлении при О. Бисмарке в 70-х гг. XIX в., когда, стремясь сохранить Османскую империю, «железный канцлер» оказал давление на Россию «на Берлинском конгрессе, что привело к определенным уступкам - учету турецких интересов», и «Россия с очевидным раздражением ответила Бисмарку на заключение в 1879 г. двустороннего германо-австрийского союза ${ }^{41}$. Однако формирование австро-германского союза не было основано на стремлении изолировать Российскую империю, что было отмечено Л. Марком в его анализе политики Бисмарка, который, оказывая поддержку Австро-Венгрии «за счёт России», тем не менее, способствовал восстановлению Союза трёх императоров в 1881 г. На нём настаивал германский канцлер в 1872-1873 гг. Изменение ситуации произошло в начале XX в., когда Германия и Австро-Венгрия начали испытывать затруднения при реализации своих внешнеполитических планов, чему в немалой степени в последнем случае способствовал подрыв «равновесия в австрийской государственной системе» из-за усиления национальных движений народов, входивших в Двуединую монархию, а также стремления Вены расширить границы империи. Поражение Российской империи на Дальнем Востоке рассматривалось эстонским историком как один из важных инициирующих факторов активизации австро-венгерской политики на Балканах ${ }^{42}$. Роль Боснийского кризиса заключалась, как считал Марк, в том, что он продемонстрировал, что «Германия определилась с цветом: с кем и против кого. Она окончательно связала себя с Австрией» ${ }^{43}$.

Обращаясь в своей статье «Русско-британские отношения в контексте русско-японской войны» ${ }^{44}$, написанной в рамках темы подготовленной им магистерской диссертации, Л. Марк отмечал, что противоборство империй за доминирующие позиции в конкретных регионах являлось основой сложившейся системы международных отношений накануне Первой мировой войны. Алгоритм действий России определялся в анализе автора статьи тем, что «отличительной особенностью англо-русских отношений в XIX в. была сильная конкуренция в Восточном вопросе. Российская экспансия на Ближнем, Среднем и Дальнем Востоке была направлена на юг к свободным ото льда морям», В тоже время эта ситуация не была статичной и, как отмечал Марк, «отношения между европейскими государствами находились в процессе формирования, свидетельствовавшем о том, что прежнее соперничество между Англией и Россией уходит в историю». Во многом это было обусловлено, по мнению автора, тем, что, как писал Марк, проводившаяся Лондоном «в конце XIX английская морская политика в значительной степени основывалась на так называемой two-power system. Потенциальными противниками выступали Франция и Россия. Английский

\footnotetext{
41 Ibid.

42 Ibid.

43 Ibid.

44 Mark L. Vene-Inglise suhted Vene-Jaapani sõja taustal.// Ajalooline Ajakiri. № 1. 1937.
} 
флот был сильнее чем флоты этих двух вместе взятых государств. Эта система начала трещать по мере того как стало известно о планах строительства военного флота Германии. Германо-английское сближение в 1900-1901 гг. провалилось. В этой связи у Британии возникла идея о том, что было бы полезно решить все важные вопросы с Францией с тем, чтобы иметь свободу рук в отношении Германии. Результатом этой политики было рождение англо-французской Антанты 18 апреля 1904 г.» ${ }^{45}$ Утверждение о колебаниях во внешнеполитических преференция Российской империи между балканским и дальневосточным векторами стало одним из важных элементов анализа российского внешнеполитического курса в эстонской межвоенной историографии. В работе Л. Марка это нашло своё отражение. Так, в частности, он отмечал, что Боксерское восстание 1900 г. в Китае усилило значение дальневосточного региона в мировой политике и привело к тому, что Российская империя «заморозила» балканское направление и активизировалась на Дальнем Востоке ${ }^{46}$.

Этот тезис «колебания» интересов между Балканами и Дальним Востоком в российской имперской политике получил дальнейшее развитие в работе другого эстонского историка -Херманна Фишера. В опубликованной им в двух номерах «Исторического журнала» за 1936 г. статьи «Балканская политика России в годы Балканских войн (октябрь 1912-октябрь 1913)»" ${ }^{47}$ в качестве одной из причин активизации российской имперской политики на Балканах рассматривалось поражение в русско-японской войне 1904-1905 гг, когда «Япония прекратила экспансию России на Дальнем Востоке» ${ }^{48}$. Особое значение автором придавалось периодизации именно империалистического характера международных конфликтов, что нашло своё отражение в опубликованной в том же журнале в 1939 г. статье «Политика Великих держав во время первого китайского кризиса в 1897-1899 гг.» ${ }^{49}$. События в Китае давали основания Х. Фишеру, использовавшему характерные для представителей лево-либеральных кругов эстонских интеллектуалов категории, считать, что «первым политическим кризисом “эпохи империализма" был китайский», а «российская политическая и экономическая экспансия ощущали на себе влияние британских успехов» ${ }^{50}$. Его выводы сводились к нескольким тезисам.

\footnotetext{
45 Цит. по электронной версии: Цит. по электронной версии: Mark L. Vene-Inglise suhted VeneJaapani sõja taustal.// Ajalooline Ajakiri. № 1. 1937.- http://www.kirjandusarhiiv.net/?p=509

46 Ibid.

${ }^{47}$ Fischer H. Venemaa Balkani-poliitika Balkani sõdade ajastul (okt. 1912 kuni okt. 1913)// Ajalooline Ajakiri. № 2; 3/ 4. 1936.

48 Цит. по электронной версии: Fischer Н. Venemaa Balkani-poliitika Balkani sõdade ajastul (okt. 1912 kuni okt. 1913)// Ajalooline Ajakiri. № 2. 1936. - http://www.kirjandusarhiiv.net/?p=521

${ }^{49}$ Fischer H. Suurriikide poliitika esimese Hiina kriisi ajal a. 1897-1899. Suurriikide poliitika esimese Hiina kriisi ajal a. 1897-1899.// Ajalooline Ajakiri. № 1. 1939.

${ }^{50}$ Цит. по электронной версии: Fischer H. Suurriikide poliitika esimese Hiina kriisi ajal a. 18971899// Ajalooline Ajakiri. № 1. 1939.- http://www.kirjandusarhiiv.net/?p=510
} 
На Балканском направлении ситуация лишь подтверждала доминирование имперского императива в во внешней политике Великих держав. Меморандум министра иностранных дел Австро-Венгрии графа Эренталя от 2 июля 1908 г., в котором предлагалось, что в обмен на согласие России с австрийской аннексией Боснии и Герцеговины российская сторона получит возможность прохода её военных кораблей через Проливы, сыграл особую роль в позиции России. В то же время, оккупация Австро-Венгрией Боснии и Герцеговины изменила баланс сил в Европе. Тройственный союз в лице Германии, Австро-Венгрии и Италии усилил свои господствующие позиции, в то время как Двойственный союз Россия и Франция, и имеющая двусторонние договоры с ними Великобритания, рассматривали боснийский кризис как усиление их слабости, и это способствовало ещё большему сплочению их военного союза. Укрепление позиций Австро-Венгрии на Балканах с опаской воспринималось в Балканских странах, так как это могло стать основой для новой экспансии Австро-Венгрии в этом направлении, а создание Балканского союза было в интересах России, стремившейся взять под контроль Проливы. При этом, как отмечал автор статьи, «вопрос Проливов не был решён в пользу России, но она была более успешной при формировании Балканского союза» ${ }^{51}$. Интересы Российской империи в отношении последнего заключались в представленном Х. Фишером анализе в том, что этот союз «1) станет инструментом влияния на его членов; 2) обеспечит расширение влияния Балканских государств; 3) разрешит болгаро-сербского конфликта; 4) передаст балканские владении Турции балканским народам» ${ }^{52}$. Судя по замечанию автора о том, «что касается последнего, Россия не была готова к этому» ${ }^{53}$, он обращал внимание на нежелание Санкт-Петербурга усиливать малые Балканские государства, имея в виду возможность перехода контроля над Проливами в пользу одного из них. Австрийский фактор в Балканских войнах рассматривался с точки зрения усиления противоречий между АвстроВенгрией и Сербией, активизации национальных движений славянских народов в Дуалистической монархии и военных приготовлений Вены ${ }^{54}$. Касаясь результатов Балканского конфликта, каковой являлась первая Балканская война, X. Фишер пиходил к выводу о том, что «к счастью для России не произошло катастрофы Балканских государств, воевавших с Турцией. Этот коллапс явился бы большим поражением для Российской политики, приблизив возможность большой войны» 55 .

Несмотря на превалировавший в исследованиях эстонских историков, занимавшихся новым и новейшим периодом всемирной истории, включая её балкан-

${ }^{51}$ Fischer H. Venemaa Balkani-poliitika Balkani sõdade ajastul (okt. 1912 kuni okt. 1913)// Ajalooline Ajakiri. № 2. 1936. - http://www.kirjandusarhiiv.net/?p=521

52 Ibid.

53 Ibid.

${ }^{54}$ Ibid.

55 Цит. по электронной версии: Fischer Н. Venemaa Balkani-poliitika Balkani sõdade ajastul (okt. 1912 kuni okt. 1913)// Ajalooline Ajakiri. № 3 / 4. 1936. - http://www.kirjandusarhiiv.net/?p=521 
ский «сектор», интерес к внешней политике Германии, России и Великобритании, и нередко достаточно косвенное обращение к австро-венгерскому аспекту Балканской политики, в середине 30 -х г. XX в. изучение роли Австро-Венгрии на Балканах активизируется. Одной из первых работ по этой теме стала статья Марты Соргсепп «Балканская политика Австро-Венгрии в 1912-1913 гг.», опубликованная в «историческом журнале в 1936 г. и посвященная одному из важных для Балканского региона периоду - двух региональных войн ${ }^{56}$. Несмотря на то, что основные постулаты, изложенные в статье не являлись новыми, они, тем не менее, свидетельствовали о попытках поиска причинно-следственных связей при формулировании внешней политики Австро-Венгрии с точки зрения складывавшегося в эстонской историографии подхода к изучению европейских империй в целом.

Так, в частности, М. Соргсепп обращала особое внимание на то, что «в период до Первой мировой войны во внутренней политике Австро-Венгрия должна была решать серьезнейшую проблему, каковой являлся национальный вопрос, имевший также важное значение для её внешнеполитического курса» ${ }^{57}$. Именно внутриполитический кризис Дуалистической монархии определялся в статье как один из решающих факторов ослабления её позиций на международной арене: «Важнейшей причиной слабости Австрии было отсутствие национальной однородности её населения. Отсутствие привлекательности монархии, национальной силы, ни один из народов не занимал доминирующих позиций. В то же время усилилось проявление центробежных сил: каждая нация стремилась к независимости и предпринимала попытки создания [собственного] государства... Чем больше конкретные народы становились активными, тем ближе становился конец Габсбургском государства. Национальный вопрос являлся фактором, который вёл к концу турецкое господство в Европе, крушению Австрии и возникновению малых Балканских государств $\rangle^{58}$. Объяснение австро-венгерской политики в балканском регионе делалась М. Соргсепп с учётом того, что «географическое расположение государства [Австро-Венгрии] и старая историческая традиция самой Австрии вела к распространению австрийского влияния и её продвижению на юг в Балканском направлении ${ }^{59}$. В соответствии с анализом внешней политики Дунайской монархии, сделанном автором статьи в «Историческом журнале», «в австрийской внешней политике на Балканах боролось две тенденции: военная, требовавшая активной политики, прежде всего, военного вмешательства с целью предотвратить усиления Сербии и Черногории, и вторая, более сдержанная, направленная на обеспечение в основном экономических и политических интересов, и в случае с Балканской войной, предпочтение было сдела-

\footnotetext{
${ }^{56}$ Sorgsepp M. Austria-Ungari Balkani-poliitika aastail 1912.-1913.// Ajalooline Ajakiri. № 3-4.1936.

57 Цит. по электронной версии: Sorgsepp М. Austria-Ungari Balkani-poliitika aastail 1912.1913.// Ajalooline Ajakiri. № 3-4. 1936.- http://www.kirjandusarhiiv.net/?p=522

58 Ibid.

${ }^{59}$ Ibid.
} 
но в пользу пассивной, выжидательной тактики» ${ }^{60}$. Сторонником первой тенденции выступал глава Генерального штаба Франц Конрад фон Хётцендорф, второй - министр иностранных дел Леопольд фон Берхтольд. В этой связи, как и другие эстонские историки, в работах которых доминировал анализ «германского фактора» в региональных и мировых делах, М. Соргеепп уделяла внимание роли Германии, союзной Австро-Венгрии, в формировании политики Вены на балканском направлении. Особое место в этом занимали договоренности между двумя союзниками от 30 октября 1912 г. В соответствии с ними Вена получала гарантии соблюдения своих интересов при взаимоотношениях с Сербией и Черногорией, а также в отношении Салоникского порта, на использование которого претендовала австрийская сторона ${ }^{61}$. Однако победа коалиции государств в составе Балканского союза в войне против Османской империи серьезно обеспокоила, как справедливо полагала М. Соргсепп, Австрию. Она начала отходить от политики сохранения status quo, опасаясь сербского продвижения к Адриатическому морю, что нашло своё выражение в поддержке независимости Албании и «Австрия была заинтересована в том, чтобы новое государство было как можно более сильным ${ }^{62}$. Оценивая в целом балканскую политику Вены, М. Соргсепп делала вывод о том, что «провал австрийской политики на Балканах произошёл не столько из-за неизбежной череды событий, которые Австрия стремилась остановить, но в большей степени из-за устаревших методов ведения австрийской дипломатии. Министр иностранных дел Бертолд не знал, как приспособить к изменяющимся условиям и использовавшиеся в недавнем прошлом традиции австрийской внешней политики» ${ }^{63}$.

Формировавшаяся в эстонской межвоенной историографии оценка роли Австро-Венгрии в системе международных отношений в конце XIX - начале $\mathrm{XX}$ в., а также характеристика её внутриполитического развития свидетельствовала о том, что Дуалистическая монархия рассматривалась как второстепенный по отношению к Германии член австро-германского блока. Действия Вены на международной арене оценивались эстонскими историками в тесной связи с внешнеполитическими планами Берлина, а внутриполитическое положение в империи Габсбургов характеризовалось как крайне нестабильное, прежде всего, ввиду нараставшей активности национальных противоречий, что выступало в работах эстонских исследователей одним из важных аргументов в пользу выдвижения тезиса доминирования Германии в Тройственном союзе.

Становление эстонской национальной историографии всемирной истории нового и новейшего времени определялось особенностями общественнополитического развития независимой с 1920 г. Эстонии и связью с историей государств и народов Балтийского региона. Именно поэтому обращение к исто-

\footnotetext{
${ }^{60}$ Ibid.

61 Ibid.

62 Ibid.

${ }^{63}$ Ibid.
} 
рии Австро-Венгрии проходило в контексте именно этой традиции. В то же время, распад Дуалистической монархии и создание новых независимых государств народов, ранее входивших в её состав, привлекал внимание эстонских историков в силу схожести процесса обретения государственной независимости их страны и её общественно-политического развития с аналогичными процессами в Центрально-Восточной Европе.

\title{
BALKANS, GERMANY AND AUSTRIA-HUNGARY ON THE EVE AND DURING WORLD WAR I IN ESTONIAN NATIONAL HISTORIOGRAPHY OF THE INTERWAR PERIOD
}

\author{
Summary
}

The article gives an overview of approaches that has been developed in interwar Estonian historiography of world affairs in the Balkans on the eve and during WWI. In that time the progress in the researchers of world history has been noticed in Estonian national historical science. Despite scarcity in their number and predominance among them of those who has been making only first steps in science, or so-called „beginners”, Estonian scholars have displayed certain achievements in this field. Young Estonian authors have focused their efforts on studies of German foreign policy combinations, internal weakness of the Austro-Hungarian Empire, strengthening of the national movements in Dual Monarchy and particular territorial interests of Great Powers. So-called young generation of the scholars has been influenced on the side of their elder ",mentors", specialists in world history, have defined Balkans as the fulcrum of WWI. The preponderance of German factor in their writings should be explained with the fact that Germany has been playing strong and active role in many spheres of Estonian life for a long time span. In some ways, it affected also sociological approach to analysis of world affairs. Both young and elder Estonian historians shared of socially oriented ideas of independent nationhood, which served as basic principal of their explanations of the international events and which has been seriously influenced by Estonia's domestic situation. 